\title{
Pengantar Editor-in-Chief Mediapsi Volume 6 Nomor 2 Tahun 2020
}

\author{
Ali Mashuri ${ }^{(1)}$ \\ ${ }^{(1)}$ Jurusan Psikologi, Universitas Brawijaya, Malang, Indonesia
}

\begin{abstract}
In this introduction, the editor-in-chief briefly described the topic of seven empirical articles that have been published in Mediapsi volume 6 number 2, 2020. Broadly speaking, the topics of the articles in this edition varied, from those of clinical psychology to educational psychology, and social psychology. The first article examined the role body dissatisfaction had in explaining subjective well-being, especially among women in emerging adulthood. The topic of the second article pertained to various aspects of the classroom atmosphere and their impacts on elementary school students' subjective well-being. Shifting the topic from elementary school students to high school students, the third article was a correlational study examining how much peer conformity and emotional intelligence predicted career adaptability. The fourth article was an experimental study, which investigated the effect of a socialisation program on the propensity of healthy behaviours among caregivers of cancer patients, followed by the fifth article zooming on in the relationship between critical thinking and religious tolerance among high school students. The sixth article was about how regional students construed the meanings of home, which was analysed qualitatively. The last, seventh article examined the levels of outgroup prejudice based on two factors, that is, intergroup contact and demographic variables (i.e., gender, age, education).
\end{abstract}

Keywords: cancer patient caregivers, career adaptability, religious tolerance, subjective well-being

Dalam pengantar ini, editor-in-chief memberikan gambaran ringkas atau kesimpulan mengenai topik tujuh artikel empiris yang telah dimuat di Mediapsi volume 6 nomor 2 tahun 2020. Secara garis besar, topik artikel dalam edisi tersebut cukup bervariasi, mulai dari psikologi klinis, psikologi pendidikan, sampai dengan psikologi sosial. Artikel pertama meneliti topik tentang peran body dissatisfaction terhadap subjective wellbeing, khususnya pada perempuan yang memasuki masa emerging adulthood. Topik kedua menelaah sejauh mana ragam aspek suasana kelas menjadi prediktor subjective well-being pada anak-anak sekolah dasar. Bergeser dari anak sekolah dasar ke remaja sekolah menengah atas, artikel ketiga merupakan studi korelasional untuk menguji peran konformitas dengan teman sebaya dan kecerdasan emosi dalam menjelaskan adaptabilitas karier. Artikel keempat adalah studi eksperimen, yang menginvestigasi pengaruh penyuluhan untuk meningkatkan kecenderungan perilaku sehat caregiver pasien kanker, diikuti dengan artikel kelima tentang hubungan antara berpikir kritis dan toleransi beragama di kalangan siswa sekolah menengah atas. Artikel keenam tentang pemaknaan rumah pada mahasiswa rantau yang menganalisis topik ini secara kualitatif. Artikel ketujuh sekaligus terakhir meneliti tinggi rendahnya prasangka terhadap kelompok lain atas dasar dua faktor, yaitu kontak antarkelompok dan variabel-variabel demografis (jenis kelamin, usia, dan tigkat pendidikan).

Kata kunci: adaptabilitas karier, caregiver pasien kanker, subjective well-being, toleransi beragama

MEDIAPSI, 2020, Vol. 6(2), 81-85, DOI: https://doi.org/10.21776/ub.mps.2020.006.02.1

Published online: 07-12-2020

*Corresponding author: Ali Mashuri, Jurusan Psikologi, Fakultas Ilmu Sosial dan Ilmu Politik, Universitas Brawijaya, Malang, Indonesia.. E-mail: alimashuri76@ub.ac.id

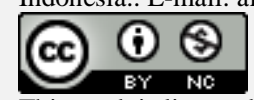

This work is licensed under a Creative Commons Attribution-NonCommercial 4.0 International License.

How to cite this article in accordance with the American Psychological Association (APA) $6^{\text {th }}$ guidelines:

Mashuri, A. (2020). Pengantar editor-in-chief mediapsi volume 6 nomor 2 tahun 2020. MEDIAPSI, 6(2), 81-85. https://doi.org/10.21776/ub.mps.2020.006.02.1

Semenjak awal Maret 2020, pemerintah Indonesia mengumumkan secara resmi bahwa COVID-19 adalah penyakit baru yang telah menjakiti negeri ini (Ihsanuddin, 2020). Krisis sosial kemudian terjadi, yang mendorong pemerintah untuk menerapkan berbagai macam 
Kebijakan untuk mencegah penyebaran penyakit menular tersebut, mulai dari pembatasan sosial berskala besar, penerapan protokol kesehatan, sampai dengan pembelajaran secara daring di semua level pendidikan (Maharani, 2020). Kebijakankebijakan tersebut membawakan berbagai macam masalah ekonomi maupun sosial bagi masyarakat (Suparman, Sakti, \& Anwar, 2020). Terlepas dari hambatan dan tantangan tersebut, tim editor merasa bersyukur bisa mempublikasikan tujuh artikel secara tepat waktu untuk volume 2 nomor 2, Desember 2020 .

Dalam edisi bulan Desember 2020 ini, artikel yang terpublikasi memiliki topik dan metodologi yang cukup bervariasi. Secara tematik, artikel mengangkat isu di bidang psikologi pendidikan, perkembangan, klinis, dan sosial. Secara metodologis, artikel ditulis sebagai laporan hasil penelitian kuantitatif maupun kualitatif. Topik spesifik, tujuan, dan hasil penelitian masing-masing artikel diuraikan secara ringkat sebagai berikut.

Artikel pertama ditulis oleh Kurnia dan Lestari (2020). Topik yang diteliti berkaitan dengan sejauh mana body dissatisfaction berperan dalam menjelaskan kesejahteraan psikologis atau psychological well-being, terutama di kalangan perempuan dalam fase emerging adulthood. Harus diakui bahwa di era sekarang ini, media berperan membangun kriteria ideal fisik yang sangat mempengaruhi penilaian individu mengenai fisik mereka (López-Guimerà, Levine, Sánchez-Carracedo, \& Fauquet, 2010). Studi korelasional dalam artikel ini nenemukan bahwa body dissatisfaction di kalangan remaja perempuan di masa emerging adulthood menurunkan aspek kepuasan hidup dan afek positif, dan sebaliknya meningkatkan afek negatif dari psychological well-being.

Ditulis oleh Aziz, Sidik, Trimansyah, Khasanah, dan Yulia (2020), artikel kedua membahas topik yang sama, yaitu subjective well-being. Hanya saja, topik ini difokuskan pada siswa sekolah dasar dan coba dijelaskan atas dasar aspek-aspek suasana kelas. Siswa sekolah dasar adalah individu yang secara perkembangan masih bergantung pada significant others, yaitu orang-orang dekat seperti orang tua dan guru (Verschueren \& Koomen, 2012). Dalam konteks ini, suasana kelas dengan demikian berperan sebagai salah satu faktor kunci yang menekankan peran guru sebagai significant others dalam membentuk subjective well-being siswa sekolah dasar. Dalam artikel ini, temuan utama melaporkan bahwa hanya jika diorientasikan pada penyelesaian tugas dan diarahkan untuk memfasilitasi adanya kolaborasi, kekompakkan, dan partisipasi aktif antar siswa, serta berkontribusi pada perasaan adil perlakukan guru terhadap siswa, suasana kelas bisa meningkatkan subjective well-being. Sementara itu, jika lebih menekankan pada dukungan guru dan pembelajaran yang berorientasi pada proses probing di dalam kelas, suasana kelas tidak berperan signifikan dalam meningkatkan subjective well-being.

Artikel ketiga merupakan hasil penelitian dari Habsari, Yusuf, dan Supratiwi (2020), sebagai sebuah studi korelasional yang menguji hubungan antara konformitas dengan teman sebaya, kecerdasan emosi, dan adaptabilitas karier pada siswa sekolah menengah atas (SMA). Menurut perspektif psikologi perkembangan, tidak bisa dipungkiri lagi bahwa kelekatan remaja bergeser dari figur terdekat (orang tua, guru) ke teman-teman sebaya (Freeman \& Brown, 2001). Dan di era saat ini yang ditandai dengan begitu cepatnya perubahan sosial, kecerdasan emosi berperan vital membekali anak anak SMA untuk mampu adaptif menghadapi tantangan jaman (Bonesso, Bruni, \& Gerli, 2020). Penelitian ini melaporkan bahwa secara simultan atau bersama sama, konformitas dan kecerdasan emosi berperan signifikan dalam menjelaskan adaptabilitas karier. Secara parsial, meskipun 
demikian, hanya kecerdasan emosional yang berperan signifikan dalam memprediksi tinggi rendahnya adaptabilitas karier.

Arvia dan Purnami (2020) adalah kontributor keempat, dengan artikel mereka yang membahas dan meneliti kecenderunga perilaku sehat pendamping atau caregiver pasien kanker. Isu kesehatan, baik fisik maupun psikis, di kalangan caregiver sangat relevan dan juga penting untuk diketahui, mengingat kerentanan mereka dalam merawat pasien anggota keluarga mereka yang menderita penyakit korinis (Schulz \& Sherwood, 2008). Melalui eksperimentasi, penelitian ini menemukan bahwa penyuluhan tentang perilaku sehat berpengaruh signifikan terhadap kecenderungan perilaku sehat caregiver. Secara empiris, hasil ini terbukti melalui skor kecenderungan berperilaku sehat caregiver yang lebih tinggi secara signifikan setelah penyuluhan (post-test) dibandingkan dengan sebelum penyuluhan (pre-test).

Artikel kelima menyelidiki keterampilan berpikir kritis dan perannya dalam menjelaskan toleransi beragama di kalangan siswa SMA, yang ditulis oleh Nugraha, Maslihah, dan Misbach (2020). Tema ini tentunya sangat upto-date karena radikalisme yang mengatasnamakan Islam masih menjadi permasalahan global maupun nasional (Mahfud dkk., 2018), yang belum secara penuh ditemukan solusinya. Trend radikalisme Islam di kalangan remaja juga menjadi keprihatian masyatakat luas, baik masyarakat akademis maupun non-akademis, di dalam maupun di luar negeri (Afrianty, 2012). Dalam artikel ini, yang didesain sebagai studi korelasional, keterampilan berpikir kritis berhubungan signifikan ke arah negatif dengan toleransi beragama. Implikasinya, tingginya keterampilan berpikir kritis berasosiasi dengan rendahnya toleransi beragama dan sebaliknya, rendahnya variabel pertama berasosiasi dengan tingginya variabel kedua.
Artikel keenam mengulas dan melaporkan hasil studi kualitatif pemaknaan rumah oleh mahasiswa rantau, ditulis oleh Prasetio, Sirait, dan Hanafitri (2020). Harus diakui bahwa di era global saat ini, mobilitas fisik individu sangat tinggi, yang dipermudah dengan berbagai macam inovasi transportasi. Mobilitas ini berdampak pada bertambahnya statistik mahasiswa daerah yang menempuh perkuliahan di luar kota atau daerah asal. Ketiga peneliti dalam artikel tersebut menemukan bahwa fenomena rindu kampung halaman atau homesickness dialami oleh mahasiswa rantau. Selain itu, mahasiswa rantau juga merasakan betapa bermaknanya rumah sebagai entitas bagi mereka yang harus tinggal di asrama atau indekos. Homesickness bagi mahasiswa rantau berkisar pada sejumlah tema, meliputi perasaan, aktivitas, rutinitas, makanan, hewan peliharaan, keluarga dan teman, suasana rumah, serta kamar. Sementara itu, mahasiswa rantau memaknai rumah di kampung halaman mereka sebagai entitas yang berasosiasi dengan "perasaan" dan "keluarga".

Artikel ketujuh sekaligus terakhir meneliti topik tentang peran kontak antarkelompok dan variabel demografi jenis kelamin, usia, dan tingkat pendidikan dalam menjelaskan fenomena prasangka terhadap kelompok lain. Artikel ini ditulis oleh Sudiana, Ihsan, dan Nurendah (2020). Prasangka terhadap kelompok lain di era sekarang ini semakin meningkat, yang salah satu penyebabnya adalah maraknya gerakan ekstremisme (Merkl \& Leonard, 2003) dan juga populisme (Kende \& Krekó, 2020). Latar belakang ini menjadikan prasangka antarkelompok menjadi sebuah topik yang sangat relevan untuk dikaji. Artikel ketujuh tersebut menemukan bahwa kontak antarkelompok secara signifikan berperan dalam mereduksi prasangka terhadap kelompok lain. Variabel demografis jenis kelamin dan usia juga berperan signifikan sebagai prediktor terhadap, tetapi tidak berperan signfikan sebagai 
moderator dalam menjelaskan hubungan antara kontak antarkelompok dan prasangka terhadap kelompok lain.

\section{Daftar Pustaka}

Afrianty, D. (2012). Islamic education and youth extremism in Indonesia. Journal of Policing, Intelligence and Counter Terrorism, 7(2), 134-146. https://doi.org/10.1080/18335330.2012.71 9095

Arvia, A., \& Purnami, I. A. M. A. (2020). Pola perilaku hidup sehat tidak hanya berlaku bagi pasien melainkan juga caregiver. MEDIAPSI, $\quad 6(2), \quad 110-118$. https://doi.org/10.21776/ub.mps.2020.006. 02.5

Aziz, R., Sidik, N. A. H., Trimansyah, Khasanah, N., \& Yulia, N. M. (2020). Model suasana kelas yang mensejahterakan siswa tingkat pendidikan dasar. MEDIAPSI, $\quad$ 6(2), 94-101. https://doi.org/10.21776/ub.mps.2020.006. 02.3

Bonesso, S., Bruni, E., \& Gerli, F. (2020). Emotional and social intelligence competencies in the digital era. In $S$. Bonesso, E. Bruni, \& F. Gerli (Eds.), Behavioral competencies of digital professionals (pp. 41-62). Palgrave Pivot, Cham. http://doi-org443.webvpn.fjmu.edu.cn/10.1007/978-3030-33578-6_3

Freeman, H., \& Brown, B. B. (2001). Primary attachment to parents and peers during adolescence: Differences by attachment style. Journal of Youth and Adolescence, 30(6), 653-674. https://doi.org/10.1023/A:1012200511045

Habsari, S. T., Yusuf, M., \& Supratiwi, M. (2020). Peran konformitas teman sebaya dan kecerdasan emosi terhadap adaptabilitas karier pada siswa Kelas XI dan XII SMA Negeri 7 Surakarta. MEDIAPSI, $\quad$ 6(2), 102-109. https://doi.org/10.21776/ub.mps.2020.006. 02.4

Ihsanuddin. (2020, Maret 02). Breaking news: Jokowi umumkan dua orang di indonesia positif corona. Kompas.com. Diakses dari https://nasional.kompas.com/read/2020/03/ 02/11265921/breaking-news-jokowiumumkan-dua-orang-di-indonesia-positifcorona?page $=$ all

Kende, A., \& Krekó, P. (2020). Xenophobia, prejudice, and right-wing populism in EastCentral Europe. Current Opinion in Behavioral Sciences, 34, 29-33. https://doi.org/10.1016/j.cobeha.2019.11.0 11

Kurnia, Y. C., \& Lestari, S. (2020). Body dissatisfaction dan keterkaitannya dengan subjective well-being pada perempuan masa emerging adulthood. MEDIAPSI, 6(2),

86-93. https://doi.org/10.21776/ub.mps.2020.006. 02.2

López-Guimerà, G., Levine, M. P., SánchezCarracedo, D., \& Fauquet, J. (2010). Influence of mass media on body image and eating disordered attitudes and behaviors in females: A review of effects and processes. Media Psychology, 13(4), 387-416.

https://doi.org/10.1080/15213269.2010.525 737

Maharani, T. (2020, September 02). Kaleidoskop 6 Bulan Pandemi Covid-19: Kebijakan Pemerintah Beserta Kritiknya...Nasional.kompas.com. Diakses dari

https://nasional.kompas.com/read/2020/09/ 02/07294641/kaleidoskop-6-bulanpandemi-covid-19-kebijakan-pemerintahbeserta-kritiknya?page $=$ all

Merkl, P., \& Leonard, W. (2003). Right-wing extremism in the twenty-first century. Hove, East Sussex, United Kingdom: Psychology Press. 
Nugraha, I., Maslihah, S., \& Misbach, I. H. (2020). Keterampilan berpikir kritis dan perannya terhadap toleransi beragama murid SMA. MEDIAPSI, 6(2), 119-131. https://doi.org/10.21776/ub.mps.2020.006. 02.6

Prasetio, C. E., Sirait. E. G. N., \& Hanafitri, A. (2020). Rumah, tempat kembali: Pemaknaan rumah pada mahasiswa rantau. MEDIAPSI, $\quad 6(2), \quad$ 132-144. https://doi.org/10.21776/ub.mps.2020.006. 02.7

Schulz, R., \& Sherwood, P. R. (2008). Physical and mental health effects of family caregiving. Journal of Social Work Education, 44(sup3), 105-113. https://doi.org/10.5175/JSWE.2008.77324 7702

Sudiana, G, N., Ihsan, H., \& Nurendah, G. (2020). Kontak antarkelompok dan demografi sebagai prediktor prasangka etnis Sunda terhadap etnis Tionghoa. MEDIAPSI, $\quad 6(2), \quad$ 145-156. https://doi.org/10.21776/ub.mps.2020.006. 02.8

Suparman, E. N.,Sakti, F. T., \& Anwar, H. S. (2020). Covid-19: Kebijakan mitigasi penyebaran dan dampak sosial ekonomi di Indonesia. LP2M UIN Sunan Gunung Djati. Diakses dari http://digilib.uinsgd.ac.id/30820/

Verschueren, K., \& Koomen, H. M. (2012). Teacher-child relationships from an attachment perspective. Attachment \& Human Development, 14(3), 205-211. https://doi.org/10.1080/14616734.2012.672 260 